\title{
THE CONCEPT OF PORTAL SYSTEM OBSTRUCTION IN AVICENNA'S CANON OF MEDICINE
}

\author{
KONCEPT OPSTRUKCIJE PORTALNOG \\ SUSTAVA U AVICENINU KANONU MEDICINE
}

\author{
Mojtaba Heydari*, Behnam Dalfardi**, Samad EJ Golzari***, \\ Syed Mohd Abbas Zaidi**** , Kamran Bagheri Lankarani*****, \\ Seyed Hamdollah Mosavat*
}

\begin{abstract}
SUMmARY
Historical literature on portal hypertension is mainly focused on the contemporary advances in therapeutic methods, especially surgical ones. However, it seems that the origin of the human knowledge on the portal system, its association with the caval system, obstructive pathologies in this system and the gastrointestinal bleeding due to hepatic diseases might be much older than previously believed.

Avicenna provided a detailed anatomy of the portal venous system and its feeding branches in the Canon of Medicine. Soddat al-Kabed va al-Masarigha (liver and mesenteric occlusion) is also a disease presented by Avicenna with clinical, etiological and therapeutic

* Research Center for Traditional Medicine and History of Medicine, Shiraz University of Medical Sciences, Shiraz, Iran.

** a. Department of Internal Medicine, Shiraz University of Medical Sciences, Shiraz, Iran. b. Student Research Committee, Shiraz University of Medical Sciences, Shiraz, Iran.

*** Liver and Gastrointestinal Disease Research Center, Tabriz University of Medical Sciences, Tabriz, Iran.

*wake Hakim Syed Ziaul Hasan Government Unani Medical College, Bhopal, India.

*watst Health Policy Research Center, Shiraz University of Medical Sciences, Shiraz, Iran.

Correspondence address: Seyed Hamdollah Mosavat, Research Center for Traditional Medicine and History of Medicine, Shiraz University of Medical Sciences, Zand St, 71397-48479 Shiraz, Iran. E-mail: hamdi_88114@yahoo.com.
\end{abstract}


descriptions suggesting the fact that Soddat al-Kabed va al-Masarigha has multiple similarities with the currently identified concept of "portal hypertension".

He presented sense of heaviness in the liver area with or without mild pain, anemia, pale and inappropriate body color, and loose stool which can be complicated with ascites, infection, fever and abdominal pain as clinical manifestations of this disease. He has also suggested therapeutic approaches including laxative and diuretic herbs to help excreting the obstructive material into stool or urine.

Keywords: portal system, portal hypertension, anatomy, history of medicine, Avicenna, liver, traditional Persian medicine

\section{INTRODUCTION}

Portal hypertension is defined as a resistance to portal blood flow and augmentation of portal collateral blood flow [I]. While the resistance most often occurs intrahepatically, as in cirrhosis, it can also be of prehepatic (e.g. portal vein thrombosis) or posthepatic (e.g., Budd-Chiari syndrome) origins. The three most common causes of portal hypertension worldwide are cirrhosis, hepatic schistosomiasis and portal vein thrombosis [2]. Portal hypertension is often asymptomatic until complications develop. The clinical manifestations of portal hypertension (such as ascites, variceal hemorrhage, spider angioma, and gynecomastia) are either related to the underlying cause or the complications of the portal hypertension. Management in patients with portal hypertension is aimed at preventing and treating its complications along with the treatment of the underlying cause [3].

Available scientific literature on history of portal hypertension is mainly focused on the recent developments in therapeutic methods especially surgical ones [4-6]. Other reports on historical origins of the findings on the portal system and portal hypertension also focused on the findings from the $\mathrm{I}^{\text {th }}$ to $2 \mathrm{O}^{\text {th }}$ centuries. In these cases, Vesalius is considered the first who mentioned the portal system in his depicted anatomical figure from this system (Figure I). At a dissection session in London, Glisson became the first to have introduced portal vein as the vessel through which blood is collected from the gastrointestinal tract and returned to the systemic circulation. His tool was a goose quill which was inserted into the portal vein and through which, using a pig's bladder, he injected milk towards liver; observing how the liver turned pale as the milk traversed it on its way to the vena cava and finally to the lungs inspired Glisson. Nineteenth century was the era in which splenomegaly, ascites, and gastrointestinal hemorrhage became known due to obstruction to the flow in the portal system [7]. 

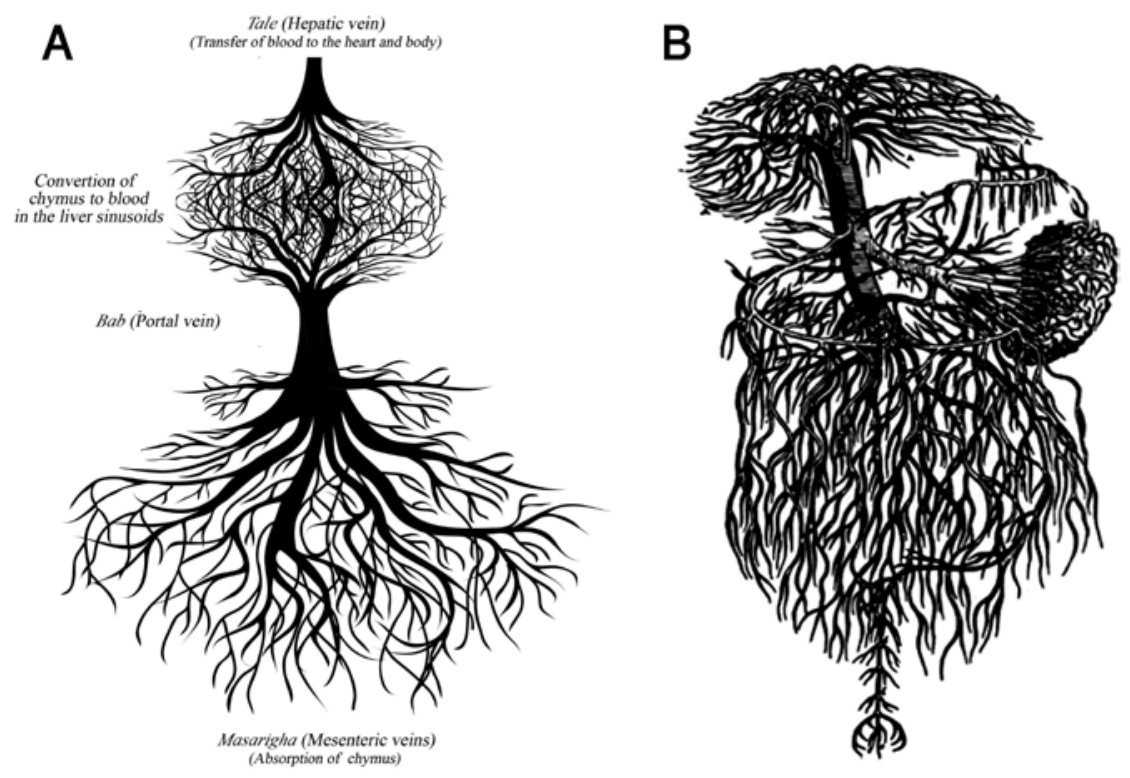

Figure I. Portal system, A: Schematic illustration of Avicenna's description of the portal system in "Canon of Medicine" (980-I037 CE). B: Vesalius's pictorial of the portal system (I543 CE).

However, it seems that the origin of the human knowledge on the portal system, its association with the caval system, obstructive pathologies in this system and the gastrointestinal bleeding due to hepatic diseases might have older origins. Our recent investigation revealed that the mentioned concepts have been presented in Avicenna's "Canon of Medicine" in the chapter of hepatic diseases especially in the discussion on the disease of "Soddat alKabed" (Liver occlusion).

Avicenna (Ibn-e-Sina), a Persian polymath born near Bukhara, Iran [now in Uzbekistan] in 980 AD, and died in Hamadan, Iran in I037, is one of the most outstanding medical scholars and practitioners of all time. He influenced the medical sciences immensely in the golden ages of Islamic medicine (9-I2th century AD) [8]. He contributed to various aspects of medicine, including gastroenterology and surgery [9]. He wrote almost 450 treatises on a wide range of subjects, including medicine [Io]. His most important medical manuscript, Al-Qanoon-fil-tibb-or (The Canon of Medicine) was translated into Latin in the I2th century AD by Constantine of Africa and was taught at the western universities from the $3_{3}$ th to the 18 th centuries AD [II-I2]. 
The Canon of Medicine is divided into five volumes. The chapter of venous system anatomy is presented in the first volume. Avicenna has discussed the portocaval venous system in this chapter. The third volume contains general principles of diagnosis and treatments of diseases of different organs. The $14^{\text {th }}$ chapter of this volume, "On the diseases of the liver" is devoted to discussion on hepatic diseases. The clinical, etiological and therapeutic description of Avicenna on the disease of "Soddat al-Kabed" in this chapter shows multiple similarities with the concept which is known today as portal hypertension. The current study reviews Avicenna's point of view on the portocaval venous system and its obstruction.

\section{DESCRIPTION OF PORTAL THE SYSTEM IN Avicenna's Canon of Medicine}

A detailed anatomy of the portal venous system and its feeding branches has been provided by Avicenna in the Canon of Medicine (Figure I) [I3].

"And in the anatomic description of vein entitled "Bab" (portal vein), we say, portal vein, in the hilum of liver, divide into five branches that consequently divide into smaller branches. These are finally drained in vein in convex part of liver (hepatic vein). The gallbladder vein is branched from these branches of portal vein (cystic vein). And these branches are like branches of a stem of a tree."

"And other side of the vein divides into eight branches. Two branches are smaller while the remaining six are larger. One of small branches connects to "Esna ashar" (duodenum) to absorb the food, and some branches to "Angheras" (pancreas) stem from this vein (pancreaticoduodenal veins). Another small branch goes to the inferior of stomach and "Bavab" of stomach (pyloric vein)."

"And of six left branches, the first goes to superficial part of stomach (left gastric vein) ..., the second one goes to the spleen (splenic vein) and some branches to "Angheras" (pancreas) leave it before reaching the spleen (pancreatic branches of splenic vein), and in entrance part of this vein to spleen a branch is split to the left side of stomach. In the spleen this vein is also divided into ascending and descending branches; some branches to the left side and cardia of stomach are divided from the ascending branch (short gastric veins) ... [and] from the descending branch another branch originates towards the left side of omentum (left gastroepiploic vein)." 
"And the third one goes to a venous plexus around the sigmoid (sigmoid vein) while the fourth stretches to the right side of stomach and omentum (right gastroepiploic vein).... The fifth distributes in colon (colic veins) and the sixth scatters around the ileum and cecum (ileocolic vein)."(vol. I, p.90-9I) [I3]

As can be seen, Avicenna has made a comprehensive description of feeding branches of portal vein in this section. He has also mentioned multiple branches precisely matching the current anatomical knowledge of these veins. However, he has described some branches with different classifications. Avicenna has also presented the anatomic and physiologic association between portal and hepatic vein through liver sinusoids.

"From the pores of "Masarigha" (mesenteric veins) the absorbed food goes toward the liver from the smaller branches to larger up to reach the "Bab" (portal vein). [Then] this vein divides into hair-like branches inside the liver and the liver tissue transfers the absorbed material to blood. Another vein originates from the convex side of liver whose stem also divides into hair-like branches connecting with branches from portal vein; through these branches blood goes from the smaller ones to larger ones up to collect whole blood into the vein having originated from the convex of liver [hepatic vein]." (vol. I, p.90-9I) [13]

\section{"Soddat Al-Kabed" clinical descriptions from Avicenna}

Described in the $\mathrm{I}^{\text {th }}$ chapter of $3^{\text {rd }}$ volume of Canon of Medicine, i.e. "On the Diseases of the liver", Soddat al-Kabed va al-Masarigha (liver and mesenteric occlusion) has been comprehensively described by Avicenna; he focuses on the clinical, etiological and therapeutic concepts of this disease suggesting the fact that Soddat al-Kabed has multiple similarities with the currently identified concept of "portal hypertension".

"The occlusion may happen in liver veins, due to abnormality in the veins such as their congenital stricture or abnormal flowing contents. The occlusion is more prevalent in pre hepatic and portal vein branches than post hepatic and hepatic vein branches, because the obstructive materials at first reach the portal branches." (vol. 3, p.183) [13]

Avicenna described the manifestations of the disease as sense of heaviness in the liver area with or without mild pain, anemia, pale and inappropriate body color and loose stool as the clinical manifestations of this disease [I3]. He also has mentioned ascites, infection, fever and abdominal pain as 
the possible complications of this disease. It seems that he is describing the clinical characteristics of secondary bacterial peritonitis in this part:

"... and [when] occlusion progresses [, it] leads to ascites and infections which cause fever and severe abdominal pain ..."(vol. 3, p.I83) [13]

He mentioned dyspnea as a consequence of this disease, comparable to what is known today as different complications of portal hypertension; for instance hepatic hydrothorax, hepatopulmonary syndrome or portopulmonary hypertension.

"The occlusion may be followed by dyspnea because the respiratory system has strong association with liver."

Avicenna does not mention bloody stool in the chapter of the disease "Soddat al-Kabed". However, he refers to symptoms which are suggestive of variceal bleeding in the chapter of the liver dystemperament.

"... Some times in the late stages of the disease the stool became similar to burned blood, not fresh one ..."(vol. 3, p.170) [13]

In another chapter, "Ekhtelaf al-Dam" (The bloody stool), he describes the differentiating symptoms of bloody stool caused by intestinal bleeding from the hepatic sources.

"The intestinal source bleeding is concomitant with abdominal cramp and is different from hepatic source bleeding which is painless and relapsing. Each relapse is worse and severer. The symptoms of liver diseases are also present in hepatic source bloody stool."(vol. 3, p.266) [I3]

He recommended against the use of astringents in the treatment of loose bloody stool with hepatic occlusive origins. According to his belief, such drugs might aggravate hepatic occlusions:

"It has occurred for multiple times that thoughtless physician-like people have used astringents in patients with liver occlusion which has ultimately led to blood thrombosis in patients' bodies, followed by the collapse of liver natural heat and death... Hence, when you diagnose the liver or mesenteric occlusion, you should focus on its treatment. Currant has been suggested for the treatment of liver and mesenteric occlusion with dark loose stool and poor condition. I have tried it on my patients and found that no exaggeration has been made on its effects."(vol. 3, p.275-276) [13] 
Splenomegaly has also been mentioned by Avicenna in a syndrome with splenic enlargement, ascites, dark stool and urine in a patient with dark jaundice.

"Dark jaundice is associated with splenic enlargement and stiffness, pain in the left side, dark stool and urine ... and splenic enlargement causes ascites and liver weakness as the spleen absorbs the blood from the liver..."(vol. 3, p.236) [13]

Avicenna has mentioned depression and psychosis as other symptoms of splenic originated jaundice, which is considered by him a consequence of atrabilious humor aggregation in the body because of spleen dysfunction.

"In the splenic originated jaundice, the patient has unexplained depression and hallucination..."(vol. 3, p.236) [13]

Avicenna quotes the poor prognosis of such patients from Hippocrates:

"Some types of jaundice are of poor prognosis and are extremely fatal. In these cases, the patients have red particles in urine, chills and fever, abdominal cramp, vertigo and inability to speak properly. Such patients will expire in I4 days." (vol. 3, p.234) [13]

He also mentioned hepatic pathologies in differential diagnosis of patients with "Sobat" (coma) in the chapter of brain diseases and recommended focusing on treatment of hepatic pathology in this kind of coma.

"Soddat Al-Kabed” ther apeutic Approaches from Avicenna

Avicenna suggested different therapeutic approaches in patients with Soddat al-Kabed including single and compound herbal formulations, dietary recommendations, enema, phlebotomy and herbal compresses on liver area.

"We need drugs with diuretic and laxative properties in the treatment of Soddat al-Kabed. When the occlusion is in the convex side of liver (post-hepatic), use the diuretics and when the occlusion is in the concave side (pre-hepatic), use the laxatives. ... The potent complicating diuretics should not be used and a diuretic with mild effects should be selected."(vol. 3, p.I85) [I3]

He also made some dietary recommendations:

"The patients should abstain from meat, refined bread, wine, rice, salt-processed foods, Khash (a traditional dish of boiled cow and sheep heads and feet in western Asia). He should also abstain from bathing, exercising and drinking large amounts of water after meal."(vol. 3, p.I87) [I3] 
Avicenna has mentioned both diuretics and laxatives in the treatment of these patients, with different concepts of their mechanism of actions. His recommendation against the use of potent diuretics, salt cured foods and drinking large amount of water shows his clinical experience in these patients. Not being aware of the effects of low protein diet, Avicenna's dietary recommendations against meat also adjust his patient's diet to be of low proteins.

Avicenna also recommended numerous herbs in "Canon of Medicine" some of which are presented in Table I.

Table r. Herbs recommended by Avicenna in "The Canon of Medicine" for "Soddat al-Kabed".

\begin{tabular}{|c|c|c|c|}
\hline $\begin{array}{l}\text { Scientific } \\
\text { name }\end{array}$ & $\begin{array}{l}\text { Common } \\
\text { name }\end{array}$ & $\begin{array}{c}\text { Traditional } \\
\text { Persian name }\end{array}$ & Pharmacologic effects \\
\hline Vitis vinifera & $\begin{array}{l}\text { Common } \\
\text { grape vine }\end{array}$ & Maviz & $\begin{array}{l}\text { Hepatoprotective, immuno- } \\
\text { modulatory }[\mathrm{I} 4, \mathrm{I} 5]\end{array}$ \\
\hline $\begin{array}{c}\text { Trigonella } \\
\text { foenum-graecum }\end{array}$ & Fenugreek & Shanbalile & $\begin{array}{l}\text { Hepatoprotective [I6], diuret- } \\
\text { ic [I7] }\end{array}$ \\
\hline $\begin{array}{l}\text { Capparis } \\
\text { spinosa }\end{array}$ & Caper & Kebar & $\begin{array}{l}\text { Hepatoprotective [I8], immu- } \\
\text { nomodulatory [19], anti-in- } \\
\text { flammatory [20] (RCT) }\end{array}$ \\
\hline $\begin{array}{l}\text { Artemisia } \\
\text { absinthium }\end{array}$ & Absinthium & Afsantin & $\begin{array}{l}\text { Antithrombotic }[2 \mathrm{I}] \text {, anti- } \\
\text { oxidant, cytoprotective }[22] \text {, } \\
\text { immunomodulatory }[23] \\
(\mathrm{RCT})\end{array}$ \\
\hline $\begin{array}{l}\text { Pistacia } \\
\text { lentiscus }\end{array}$ & Mastic & Mastaki & $\begin{array}{l}\text { Anthelmintic }[24] \text {, hepato- } \\
\text { protective }[25]\end{array}$ \\
\hline $\begin{array}{l}\text { Cichorium } \\
\text { intybus }\end{array}$ & Chicory & Kasni & $\begin{array}{c}\text { Hepatoprotective, diuretic, } \\
\text { anti-inflammatory, anti-oxi- } \\
\text { dative, immunomodulating } \\
{\left[{ }_{2} 6\right](\mathrm{RCT})}\end{array}$ \\
\hline $\begin{array}{l}\text { Apium } \\
\text { graveolens }\end{array}$ & Celery & Karafs & $\begin{array}{l}\text { Hepatoprotective [27], diuret- } \\
\text { ic }[28](\mathrm{RCT})\end{array}$ \\
\hline $\begin{array}{l}\text { Matricaria } \\
\text { chamomilla }\end{array}$ & Chamomile & Baboneh & $\begin{array}{l}\text { Hepatoprotective [29], an- } \\
\text { ti-platelet [30] }\end{array}$ \\
\hline
\end{tabular}

\section{Discussion ANd Conclusion}

Numerous primary documented reports of the findings on the portal system and portal hypertension appear in the western medicine from the $\mathrm{I}^{\text {th }}$ to $2 \mathrm{O}^{\text {th }}$ centuries with definite descriptions of splenomegaly, ascites, and gastrointestinal hemorrhage in the nineteenth century. Vesalius is generally 
believed to have presented the first depiction of the portal system and its classification followed by Glisson having introduced portal vein and its function based on an animal model.

Based on the findings from the Canon of Medicine, Avicenna (980-1037 AD), presented the detailed anatomy of the portal venous system and its feeding branches much earlier than his western counterparts. Most of these descriptions precisely match their current anatomical knowledge. In addition, he also presented the anatomic and physiologic association between portal and hepatic vein through liver sinusoids. Notably, he presented clinical, etiological and therapeutic concepts of portal hypertension under the name of "Soddat al-Kabed". His description of the manifestations of portal hypertension are accurate and comprehensive, and he explained signs like sense of heaviness in the liver area with or without mild pain, anemia, pale and inappropriate body color, and loose stool. Furthermore, he mentioned ascites, infection, fever and abdominal pain (probably, clinical characteristics of the secondary bacterial peritonitis) as the possible complications of portal hypertension.

Avicenna was not the only scholar of both Antiquity and the Medieval Age who discussed on the anatomy, physiology and diseases of the liver and portal system. The liver was known as blood-rich organ among Egyptians, Babylonians and Mediterranean people since antiquity [3I]. It seems that their knowledge of anatomy of liver originated from the inspection of sacrificed animals in rituals of divination [32]. The liver was considered as the "seat of life" and named with the terms similar to the term "life" in Indian, German and English languages [33]. Greek and Roman practitioners considered the liver as one of the three main organs, along with the brain and the heart. Aristotle believed that the vena cava supplies the liver with blood from above. Galen, in contrast, considered the liver as the source of blood production which supplies other organs with blood through veins. Medieval scholars mostly followed Galen idea about the liver and considered it as the origin of Natural Power and also source of production of four humors which was send through veins for body nourishment and growth [34]. Galen also reported from his Alexandrian ancestors about connecting channels in the liver between portal vein to the vena cava. The Greek and Roman differentiated portal, caval and biliary vessels in the liver. Liver obstruction was also described by Galen as the coagulation of the yellow bile in bile ducts which can lead to jaundice [35]. However Avicenna seems to be the first who mentioned the possible obstruction in the portal system and its consequent complications and manifestations such as ascites and gastrointestinal bleeding in details. 


\section{REFERENCES}

1. J.C. García-Pagán, J. Gracia-Sancho, J. Bosch, Functional aspects on the pathophysiology of portal hypertension in cirrhosis, J. Hepatol. 57 (2012) 458-461.

2. A. Berzigotti, S. Seijo, E. Reverter, J. Bosch, Assessing portal hypertension in liver diseases, Expert. Rev. Gastroenterol. Hepatol. 7 (2013) 141-155.

3. S. Møller, J.H. Henriksen, F. Bendtsen, Extrahepatic complications to cirrhosis and portal hypertension: Haemodynamic and homeostatic aspects. World. J. Gastroenterol. 20(2014) 15499-517.

4. Y. Idezuki, N. Murata, The history of the treatment for portal hypertension, Nihon Geka Gakkai Zasshi. 97 (1996) 4-12.

5. JG. Chandler, The history of the surgical treatment of portal hypertension, Arch. Surg. 128 (1993) 925-940.

6. I. Dzeletovic, T.H. Baron, History of portal hypertension and endoscopic treatment of esophageal varices, Gastrointest. Endosc. 75 (2012) 1244-1249.

7. P. Sandblom, The history of portal hypertension, J. R. Soc. Med. 86 (1993) 544.

8. S.E. Golzari, Z.H. Khan, K. Ghabili, H. Hosseinzadeh, H. Soleimanpour, R.et al, Contributions of medieval Islamic physicians to the history of tracheostomy. Anesth. Analg. 116(2013) 1123-32.

9. A. Dabbagh, S. Rajaei, S.E. Golzari, History of Anesthesia and Pain in Old Iranian Texts. Anesth. Pain. Med. 4(2014):e15363.

10. M. Heydari, M.H. Hashempur, A. Zargaran, Medicinal aspects of opium as described in Avicenna's Canon of Medicine, Acta. Med. Hist. Adriat. 11 (2013) 101-112.

11. MM. Shoja, R.S. Tubbs, M. Loukas, M. Khalili, F. Alakbarli, AA. Cohen Gadol, Vasovagal syncope in the Canon of Avicenna: the first mention of carotid artery hypersensitivity, Int. J. Cardiol. 134 (2009) 297-301.

12. N.G. Siraisi, Avicenna in Renaissance Italy: the Canon and medical teaching in Italian universities after 1500, Princeton University Press, Princeton, (2014).

13. IbneSina H. Al-Qanoon fi al-Tibb (The Canon of Medicine). Beirut: Dare Ehia Attorath Al Arabi; 2005. In Arabic.

14. Orhan DD, Orhan N, Ergun E, Ergun F. Hepatoprotective effect of Vitis vinifera L. leaves on carbon tetrachloride-induced acute liver damage in rats. J Ethnopharmacol. 2007 May 30;112(1):145-51. Epub 2007 Feb 20. PubMed PMID: 17391882.

15. T. Liu, J. Zhao, L. Ma, Y. Ding, D. Su, Hepatoprotective Effects of Total Triterpenoids and Total Flavonoids from Vitis vinifera L against Immunological Liver Injury in Mice. Evid. Based. Complement. Alternat. Med. 2012 (2012);2012:969386. doi: 10.1155/2012/969386. Epub 2012 Jan 4. PubMed PMID: 22262981; PubMed Central PMCID: PMC3259503. 
16. R. Meera, P. Devi, B. Kameswari, B. Madhumitha, N.J. Merlin, Antioxidant and hepatoprotective activities of Ocimum basilicum Linn. and Trigonella foenum-graecum Linn. against $\mathrm{H} 2 \mathrm{O} 2$ and CCL4 induced hepatotoxicity in goat liver, Indian. J. Exp. Biol. 47 (2009) 584-590.

17. R.M. Rohini, N. Nayeem, A.K. Das, Diuretic effect of Trigonella foenum-graecum seed extracts, The Inter. J. Alternat. Med. 6 (2009).

18. H.F. Huseini, S.M. Alavian, R. Heshmat, M.R. Heydari, K. Abolmaali, The efficacy of Liv-52 on liver cirrhotic patients: a randomized, double-blind, placebo-controlled first approach, Phytomedicine. 12 (2005) 619-624.

19. A. Arena, G. Bisignan, B. Pavone, A. Tomaino, F.P. Bonina, A. Saija, et al., Antiviral and immunomodulatory effect of a lyophilized extract of Capparis spinosa L. buds, Phytother. Res. 22 (2008) 313-317.

20. H. Zhou, R. Jian, J. Kang, X. Huang, Y. Li, C. Zhuang, et al., Anti-inflammatory effects of caper (Capparis spinosa L.) fruit aqueous extract and the isolation of main phytochemicals, J. Agric. Food. Chem. 58 (2010) 12717-12721.

21. SK. Açıkgöz, E.Açıkgöz, Gastrointestinal bleeding secondary to interaction of Artemisia absinthium with warfarin. Drug. Metabol. Drug. Interact. 28 (2013) 187-189.

22. O. Craciunescu, D. Constantin, A. Gaspar, L. Toma, E. Utoiu, L.Moldovan, Evaluation of antioxidant and cytoprotective activities of Arnica montana L. and Artemisia absinthium L. ethanolic extracts, Chem. Cent. J. 6 (2012) 97.

23. B. Omer, S. Krebs, H. Omer, T.O. Noor, Steroid-sparing effect of wormwood (Artemisia absinthium) in Crohn's disease: a double-blind placebo-controlled study, Phytomedicine. 14 (2007) 87-95.

24. S. Landau, H. Azaizeh, H. Muklada, T. Glasser, E.D. Ungar, H. Baram, et al., Anthelmintic activity of Pistacia lentiscus foliage in two Middle Eastern breeds of goats differing in their propensity to consume tannin-rich browse, Vet. Parasitol. 173 (2010) 280-286.

25. P. Ljubuncic, H. Song, U. Cogan, H. Azaizeh, A. Bomzon, The effects of aqueous extracts prepared from the leaves of Pistacia lentiscus in experimental liver disease, J. Ethnopharmacol. 100 (2005) 198-204.

26. H.F. Huseini, S.M. Alavian, R. Heshmat, M.R. Heydari, K. Abolmaali, The efficacy of Liv-52 on liver cirrhotic patients: a randomized, double-blind, placebo-controlled first approach, Phytomedicine. 12 (2005) 619-624.

27. A. Singh, S.S Handa, Hepatoprotective activity of Apium graveolens and Hygrophila auriculata against paracetamol and thioacetamide intoxication in rats, J. Ethnopharmacol. 49 (1995) 119-126.

28. M.H. Moghadam, M. Imenshahidi, S.A. Mohajeri, Antihypertensive effect of celery seed on rat blood pressure in chronic administration, J. Med. Food. 16 (2013) 558-563. 
29. H.S. Tavakol, K. Farzad, M. Fariba, C. Abdolkarim, G. Hassan , H.Z. SeyedMostafa, et al., Hepatoprotective Effect of Matricaria chamomilla.L in Paraquat Induced Rat Liver Injury, Drug. Res. (Stuttg). (2014). Epub ahead of print.

30. M. Bijak, J. Saluk, M. Tsirigotis-Maniecka, H. Komorowska, B. Wachowicz, E. Zaczyńska, et al., The influence of conjugates isolated from Matricaria chamomilla L. on platelets activity and cytotoxicity, Int. J. Biol. Macromol. 61 (2013) 218-229.

31. Reuben A, Groszmann RJ. Portal Hypertension. Portal Hypertension: Springer; 2005. p. 3-11.

32. Martins ACdA, Martins C. History of liver anatomy: Mesopotamian liver clay models. HPB. 2013;15(4):322-3.

33. Kuntz E, Kuntz H-D. History of hepatology. Hepatology Textbook and Atlas: History· Morphology Biochemistry· Diagnostics Clinic· Therapy. 2008:1-13.

34. Shahkarami E, Minaei B, Dehkordi EJ. The concept of liver disease diagnosis in Avicenna's canon of medicine. Iranian journal of public health. 2013;42(7):785.

35. Ursin F, Steger F. Gallstones and" liver obstruction" in medical texts of antiquity. Zeitschrift für Gastroenterologie. 2018;56(3):249-54.

\section{SAŽETAK}

Povijesna literatura o portalnoj hipertenziji uglavnom je usredotočena na suvremeni napredak u terapijskim metodama, posebice kirurškim. Čini se, međutim, da ljudsko znanje o portalnom sustavu, njegovo povezivanje sa sustavom šuplje vene, patologije opstrukcija u tom sustavu $i$ gastrointestinalno krvarenje zbog bolesti jetre može biti znatno starije nego što se prije vjerovalo.

Avicenna je dao detaljnu anatomiju portalnoga venskog sustava i njegovih grana u Kanonu medicine. Soddat al-Kabed va al-Masarigha (jetra i okluzija mesenterijskih žila) bolest je koju je Avicenna predstavio kliničkim, etiološkim i terapeutskim opisima koji upućuju na to da ima puno sličnosti s identificiranim pojmom "portalne hipertenzije".

Avicenna je istaknuo osjećaj težine u području jetre s blagom boli ili bez nje, anemiju, blijedu i neodgovarajuću boju tijela te mekanu stolicu koja se može zakomplicirati ascitesom, infekcijom, groznicom i bolovima u trbuhu kao kliničkim manifestacijama ove bolesti. Predložio je i terapeutske pristupe, uključujući laksativi diuretičke trave, kako bi se izbjeglo izlučivanje opstruktivnih tvari u stolici ili urinu.

Ključne riječi: portalni sustav, portalna hipertenzija, anatomija, povijest medicine, Avicenna, jetra, tradicionalna perzijska medicina 